\title{
Ordovician Fauna in a Small Fault Block on the Yarrol Fault, South of Calliope, Central Queensland
}

\author{
Peter A. Jell ${ }^{1,2}$, Ian G. Percival ${ }^{3}$ and Alex G. Cook $^{1,2}$
}

\begin{abstract}
Fossils, comprising sponge spicules, brachiopods, trilobites and assorted echinoderm plates, from a fault-bounded sliver along the Yarrol Fault $30 \mathrm{~km}$ south-south-east from the town of Calliope in central eastern Queensland, are described and illustrated for the first time. Due to their poor preservation, none of the fossils are identifiable to species level, but the trilobites, Arthrorhachis sp. and two pliomerid pygidia, belong to taxa not known outside the Ordovician, and Illaenus sp. compares closest with Middle Ordovician members of the genus. The brachiopods - including orthoids (?Phaceloorthis among others), plectambonitoids (Sericoidea), the protorthide Skenidioides and a siphonotretide - resemble forms previously described from the Late Ordovician (Katian) of central New South Wales and indicate an open marine deep-water habitat (120-200 m depth). This assemblage is significant in representing the first Ordovician fauna (and the oldest fossils) documented from the New England Orogen in Queensland. The tectonic implications of this confirmed Ordovician sedimentary succession within the New England Orogen in central Queensland are yet to be fully appreciated, but it does complement similarly aged successions occurring along the Peel Fault in the southern New England Orogen. Together these tiny fault blocks suggest that the island arc or arcs which developed during the early Palaeozoic were incorporated into the New England Orogen during the middle Palaeozoic, both in its northern part as well as in the south.
\end{abstract}

Keywords: Ordovician, shelly fossils, fault block, New England Orogen, Yarrol Fault

\author{
${ }^{1}$ School of Earth Sciences, The University of Queensland, St Lucia, Qld 4072, Australia \\ (amjell@bigpond.com) \\ ${ }^{2}$ Geosciences Program, Queensland Museum, 122 Gerler Road, Hendra, Qld 4011, \\ Australia \\ ${ }^{3}$ Geological Survey of New South Wales, 947-953 Londonderry Road, Londonderry, \\ NSW 2753, Australia
}

Jell, P. A., Percival, I. G., \& Cook, A. G. (2021). Ordovician fauna in a small fault block on the Yarrol Fault, south of Calliope, central Queensland. Proceedings of The Royal Society of Queensland, 129, x-xx. https://doi.org/10.53060/prsq.2021.4

\section{Introduction}

Eastern Australia has been thoroughly investigated by many geologists in the last 200 years and found to have had a structurally complex early Palaeozoic history (540-440 mya) made more difficult to interpret by later Palaeozoic (440-250 mya) orogenic events and the long period of weathering that has followed up to the present (Fergusson \& Henderson, 2015; Glen, 2005). In Victoria, fossiliferous Cambrian rocks are sparsely represented, whereas Ordovician rocks, predominantly characterised by rich graptolite faunas, are widely distributed throughout the Lachlan Orogen, with rare occurrences of earliest and latest Ordovician shelly faunas at Waratah Bay and Deep Creek, respectively (Birch, 2003). Further north in eastern New South Wales, Cambrian fossils are only known from two isolated localities, one on the south coast

This work is licensed under a Creative Commons Attribution-NonCommercial-NoDerivatives 4.0 International Licence. Individual articles may be copied or downloaded for private, scholarly and not-for-profit use. Quotations may be extracted provided that the author and The Royal Society of Queensland are acknowledged. Queries regarding republication of papers, or parts of papers such as figures and photographs, should be addressed to the Secretary of The Royal Society of Queensland (rsocqld@gmail.com). 
and the other in the Tamworth-Nundle district in the New England Orogen (Packham, 1969; Percival et al., 2011). Ordovician faunas are widespread in the Lachlan Orogen in central and southern New South Wales where a complete spectrum of water depths from basinal cherts through open marine graptolitic shales to shallow water limestones with abundant shelly fossils fringing volcanic islands have been interpreted (Percival et al., 2011 and references therein). Ordovician fossiliferous rocks are also known from the Narooma Terrane on the south coast, and in parts of the southern New England Orogen adjacent to the Peel Fault near Tamworth and in the Port Macquarie area (Percival et al., 2011). However, in eastern Queensland, Cambrian fossils are yet to be discovered and fossiliferous Ordovician rocks are known only from the Broken River Province of the Mossman Orogen (Withnall \& Lang, 1993; Dixon \& Jell, 2012; Zhen et al., 2015), Charters Towers Province south-west of Townsville (Henderson, 1983) and the Fork Lagoons Subprovince of the Anakie Province (Fergusson \& Withnall, 2012; Palmieri, 1978), both the latter in the Thomson Orogen. This paper identifies age constraints, based on palaeontological evidence, for the reported Ordovician age (Blake, 2013) of a small fault block on the Yarrol Fault about $30 \mathrm{~km}$ south-south-east of Calliope in central Queensland. Its significance is that, in contrast with the other Queensland Ordovician faunas just mentioned, it occurs within the New England Orogen (Murray et al., 2012).

\section{Geological Setting}

The New England Orogen is a major meridionally oriented tectonic feature in eastern Australia, exposed over $1500 \mathrm{~km}$ from the Hunter River Valley of New South Wales through central eastern Queensland as far north as Bowen (Glen, 2013; Donchak et al., 2013). Its depositional history is well represented by Silurian to Triassic age rocks. Rare outcrops of Cambrian and Ordovician strata are confined to fault blocks adjacent to major faults near Tamworth, northern New South Wales, and in central eastern Queensland near Calliope; the latter is the subject of this paper. Other Ordovician sedimentary rocks, as mentioned above, are known from scattered occurrences in the Thomson and Mossman orogens in central and north-eastern Queensland.
Allochthonous Ordovician blocks and clasts are also present in younger (Silurian and Devonian) deposits, suggesting that Cambrian and Ordovician strata were widely distributed in the region prior to their erosion, redeposition and tectonic upheaval.

The relative rarity of lower Palaeozoic rocks, and fossil evidence of their ages, in the New England Orogen provides impetus for documentation of poorly known or new occurrences. In this contribution we describe trilobites and brachiopods from an infaulted block adjacent to the Yarrol Fault, on the 'Santa Glen' property $30 \mathrm{~km}$ south-south-east of the town of Calliope in the northern part of the exposed New England Orogen, central eastern Queensland. During regional field mapping of the New England Orogen in central Queensland by the Geological Survey of Queensland, Paul Blake discovered a fossiliferous horizon in a roadside channel on a station track at $24^{\circ} 14^{\prime} 17^{\prime \prime} \mathrm{S}, 151^{\circ} 18^{\prime} 52^{\prime \prime} \mathrm{E}$, about one kilometre north-west of the Santa Glen homestead (Figure 1). He sent two samples to one of us (PAJ) for identification. One of these specimens had a cluster of large monaxon spicules, and the other was an articulated, badly damaged, pliomerid trilobite. On two subsequent occasions the senior author has spent hours collecting on the site, and the fauna described here is the result of that search. This locality was first mentioned in the literature (see Blake in Murray et al., 2012, p. 9; Blake, 2013, p. 311) as having Ordovician fossils of two different ages, but the fauna has not previously been illustrated or discussed in detail. The occurrence is of considerable significance in representing the sole known Ordovician fauna in the northern New England Orogen, and supports informed biostratigraphic correlation with the limited Ordovician sedimentary rocks previously recognised from the adjacent Thomson Orogen in central Queensland.

Blake (2013) also reported conodont-bearing limestones at two separate sites in the area. These conodonts have been briefly commented on and accorded Ordovician ages by Fordham (2012, table 1), but the identification and description of the conodonts from either site have not been published. One of the sites is interbedded in the same succession as the shelly fossils described herein, whereas the other, near the Santa Glen homestead, is a reworked boulder from a conglomerate that also contains Devonian clasts. 

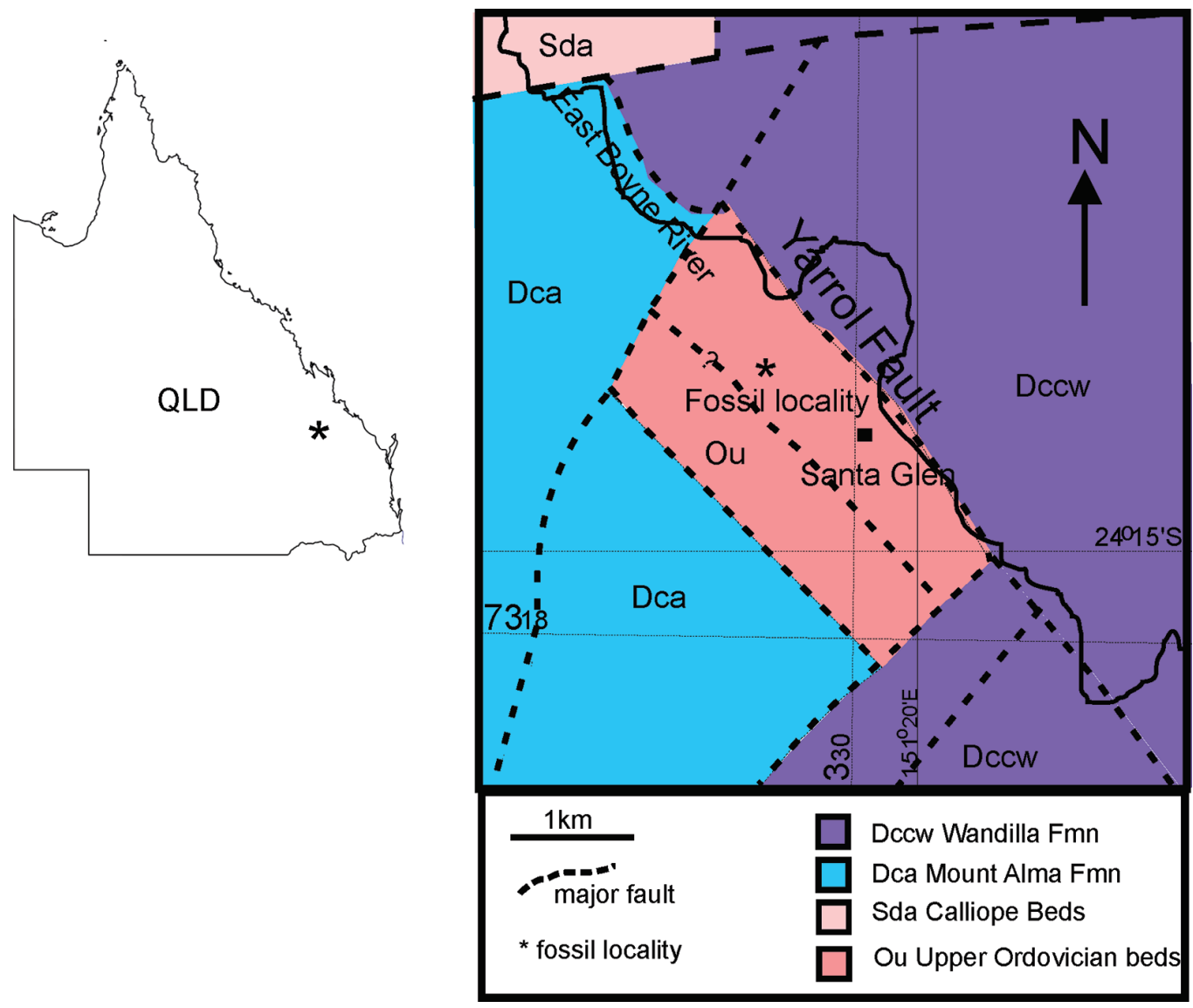

FIGURE 1. Locality map, showing the collection site relative to Santa Glen, the Yarrol Fault and surrounding geology. Redrawn from the 2001, 1st ed., Calliope 1:100,000 Geological Sheet (9149), Queensland Department of Natural Resources and Mines.

Although its boundaries are unclear due to poor outcrop, the succession containing the fossils described herein is interpreted as coming from a small fault-bounded sliver between other fault blocks of the Calliope beds (Murray et al., 2012) and bounded to the east by the regionally significant Yarrol Fault. The fault block is mapped on the Calliope 1:100,000 geological map published by the Queensland Department of Natural Resources and Mines in 2001. Within this fault block is a succession of well-sorted, fine- to medium-grained and thin-bedded volcaniclastic siltstone, sandstone and conglomerate sourced from basaltic to andesitic lavas and with minor interbedded conodont-bearing limestone. The volcaniclastic sedimentary rocks are well-sorted and the clasts are well-rounded. One of the fine-grained, siliceous siltstone units contains the sponges, brachiopods and trilobites, and a single limestone horizon yielded a meagre conodont fauna dated as Floian (late Early Ordovician) by Fordham (2012), though no identifications nor illustrations of the conodonts were given. Detailed description of the fault block is provided by Murray et al. (2012).

Limestone from a site near the Santa Glen homestead yielded an abundant and diverse Late Ordovician conodont fauna, not identified but reported to be comparable with eastern Australian faunas of that age (Fordham, 2012). This limestone block comes from a conglomerate that also contains Devonian limestone clasts and is interpreted as part of the Calliope beds and not part of the Ordovician fault block. 


\section{Geological Significance}

The extensive compilation of the geological history of eastern Australia, termed the Tasmanides (Glen, 2005), though modified in some details in recent years, provides a background for the significance of the fauna described herein. In eastern Australia several major accretionary orogenic events have been interpreted along the eastern margin of Gondwana during the Palaeozoic (Glen, 2005; Fergusson \& Henderson, 2015; Jessop et al., 2019). The older Delamerian, Lachlan and Thomson orogens to the west of the New England Orogen all have Cambrian and Ordovician histories. However, the younger, more easterly New England Orogen has very few clues to its Cambrian or Ordovician history in New South Wales (Glen, 2005, fig. 4b) and none at all in Queensland (Glen, 2005, fig. 4c). Discovery of this Ordovician fault block provides the first clues to the earlier geological history of the orogen in Queensland. Although unique, and much older than any other sedimentary units in the Queensland part of the New England Orogen, possible correlatives of these rocks may be found in Cambrian to Ordovician fault blocks along the Peel Fault near Tamworth in the southern New England Orogen (Packham, 1969; Cawood, 1976). The Peel Fault in New South Wales has been interpreted as an extension of the Yarrol Fault in Queensland, though interrupted by the Texas and Coffs Harbour oroclinal structures in the central New England Orogen (Donchak et al., 2013, figs 5.1, 5.2).

Numerous late Silurian to Middle Devonian fault blocks in the Yarrol Province of central eastern Queensland have igneous rocks that are chemically comparable to those of modern island arcs and are interpreted as being remnants of an island arc setting (Murray et al., 2012). The possibility of earlier, island arc development is now raised by the discovery of this very small fault block rich in volcanogenic sediments, and herein reliably dated as Ordovician.

\section{Systematic Palaeontology}

Phylum PORIFERA

\section{Monaxon spicules indet. (Figure 2)}

\section{Material. QMF60314, QMF60315.}

Description. The spicules are straight, circular in cross-section, and taper to a sharply pointed tip in all observed terminations. The largest spicule available is $15 \mathrm{~mm}$ long and $0.5 \mathrm{~mm}$ in diameter. Whether the twisted tuft of finer, apparently shorter elongate elements or spicules (Figure 2C) is part of a sponge body or a root mass is not certain.

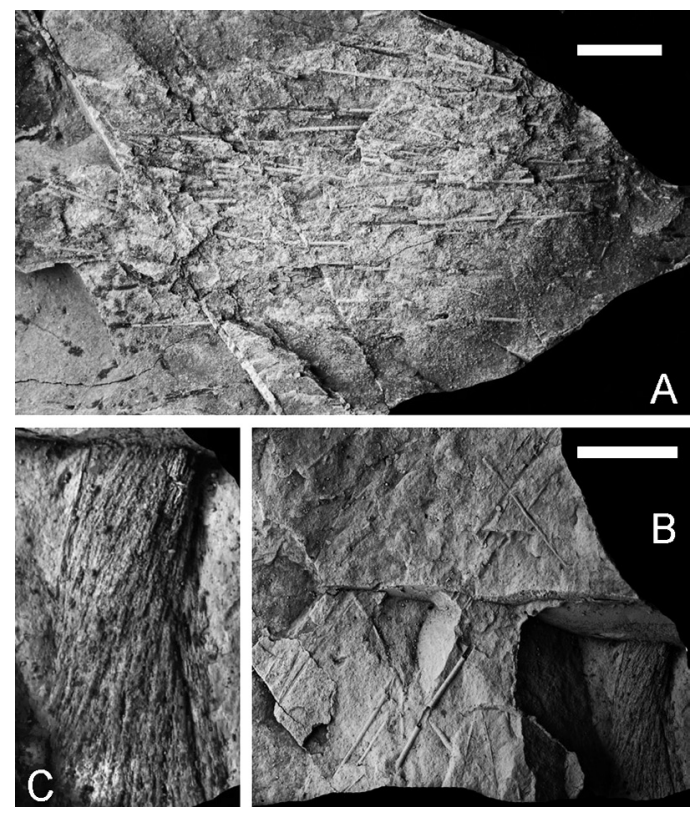

FIGURE 2. Monaxon sponge spicules indet.

A, QMF60314, mass of large long spicules aligned subparallel to each other and preserved as silica. B, QMF60315, few widely separated spicules with some at high angle. $\mathrm{C}$, enlargement of tuft of much finer spicules in lower right in B. Scale bars $=5 \mathrm{~mm}$.

Remarks. The paucity of available specimens and their less than ideal preservation allow two possible interpretations for these spicule assemblages.

An Ordovician (Darriwilian) sponge fauna from Wales (Botting, 2005) includes a species of Pyritonema McCoy, 1850 that bears resemblance to our Queensland material. Botting (2005) erected the Pyritonemidae as a monogeneric family for Pyritonema. Without entering into any issues of sponge classification, we note that his familial diagnosis would admit our Queensland material, his generic diagnosis less so. In our material large spicules generally isolated and probably dislodged from the skeleton (Figure 2A,B) are an order of magnitude larger than those in a twisted tuft (Figure 2C) that might easily be interpreted 
as a root tuft. However, the Welsh material shows a similar size range (Botting, 2005, fig. 14D,H) within the body of the sponge.

Alternatively, these spicules may be assigned to the Protomonaxonida Finks \& Rigby, 2004, which is characterised as having "fibrous skeletons composed only of oxeas" (Finks \& Rigby, 2004, p. 9) and to the Ascospongiae Botting, 2021, a new name for part of the polyphyletic Protomonaxonida. Most known members of the class occur in the Cambrian, but a post-Cambrian Australian representative is Musaspongia amnicola Jell \& Cook, 2011, from the Lower Devonian of Victoria. Several authors have inferred close relationships between protomonaxonids and various sponge taxa throughout the geological column (Botting et al., 2013). The assemblage of spicules (Figure 2A) is very reminiscent of the illustration of Halichondrites elissa Walcott, 1920 (see Finks \& Rigby, 2004, fig. 13) from the Middle Cambrian Burgess Shale, which genus was noted by Botting \& Muir (2018, p. 12) as representing "... more derived parts of this lineage include Halichondrites ...”. Post-Cambrian relatives might, therefore, be expected.

Although it is tempting to assign our Queensland material to the Pyritonemidae, because its Welsh occurrence is in similar volcanogenic sediments and matches approximately the age we infer for our collecting site, we remain open-minded given the poor quality of our material and the difficulty of interpreting this type of specimen within current poriferan classification. These spicules offer little information on age but are recorded to illustrate the presence of sponges in the fauna.

\section{Phylum BRACHIOPODA}

Class LINGULATA Gorjansky \& Popov, 1985

Order SIPHONOTRETIDA Kuhn, 1949

Family SIPHONOTRETIDAE Kutorga, 1848

Siphonotretid indet. (Figures 3A, 4E)

Material. QMF60316, external mould of a ?dorsal valve and QMF60349, fragment of an external mould (valve indeterminate).

Description. Ornamentation consists of radial ribs intersecting strong concentric lamellae that apparently bear small remnants of spine bases (particularly on the two most anterior lamellae of the specimen in Figure 3A).

Remarks. Although these external moulds are difficult to identify because internal features are not preserved and no ventral valve is definitely known, the ornamentation is distinctive and supports assignment to the Siphonotretidae. Comparable specimens dissolved from limestone of Katian age have been described from the Broken River Province, north Queensland. In such specimens, identified as Nushbiella Popov in Kolobova \& Popov, 1986 (see Zhen et al., 2015, fig. 18d,e), the external surface is badly eroded and only tiny spine bases are preserved, similar in appearance to those figured here.

Class STROPHOMENATA Williams, Carlson,

Brunton, Holmer \& Popov, 1996

Order STROPHOMENIDA Öpik, 1934

Superfamily PLECTAMBONITOIDEA Jones, 1928

Family XENAMBONITIDAE Cooper, 1956

Subfamily AEGIROMENINAE Havlíček, 1961

Sericoidea Lindström, 1953

Type Species. Leptaena sericea J. de C. Sowerby var. restricta Hadding, 1913 from the Sularp Shale (Sandbian), Fågelsång, Sweden; by original designation.

Remarks. In an extensive review of all known species, Candela (2011) clearly distinguished Sericoidea from Chonetoidea Jones, 1928, with which the former had been synonymised by Cocks \& Rong (2000). Sericoidea is restricted to rocks of Late Ordovician age, ranging from the lower Sandbian to middle Katian. It has a widespread distribution, having been described from Australia (New South Wales), USA (Virginia, Tennessee), Ireland, Scotland, Wales, Norway and Sweden. Two species are known from New South Wales, S. sejuncta Percival, 1979 and S. minor Percival, 1979, which are contemporaneous and confined to the middle Katian. They represent the youngest known species of Sericoidea.

Wherever it occurs, Sericoidea is restricted to deeper water clastic sediments as deep as Benthic Association (BA) 5. In his review of the genus, Candela (2011) analysed all known occurrences and determined a bathymetric window ranging from $120 \mathrm{~m}$ to over $200 \mathrm{~m}$ water depth. Thus, recognition of Sericoidea in the faunal assemblage from south of Calliope is very significant in not only constraining the age of the fauna but also assisting in interpretation of its likely depositional environment. 

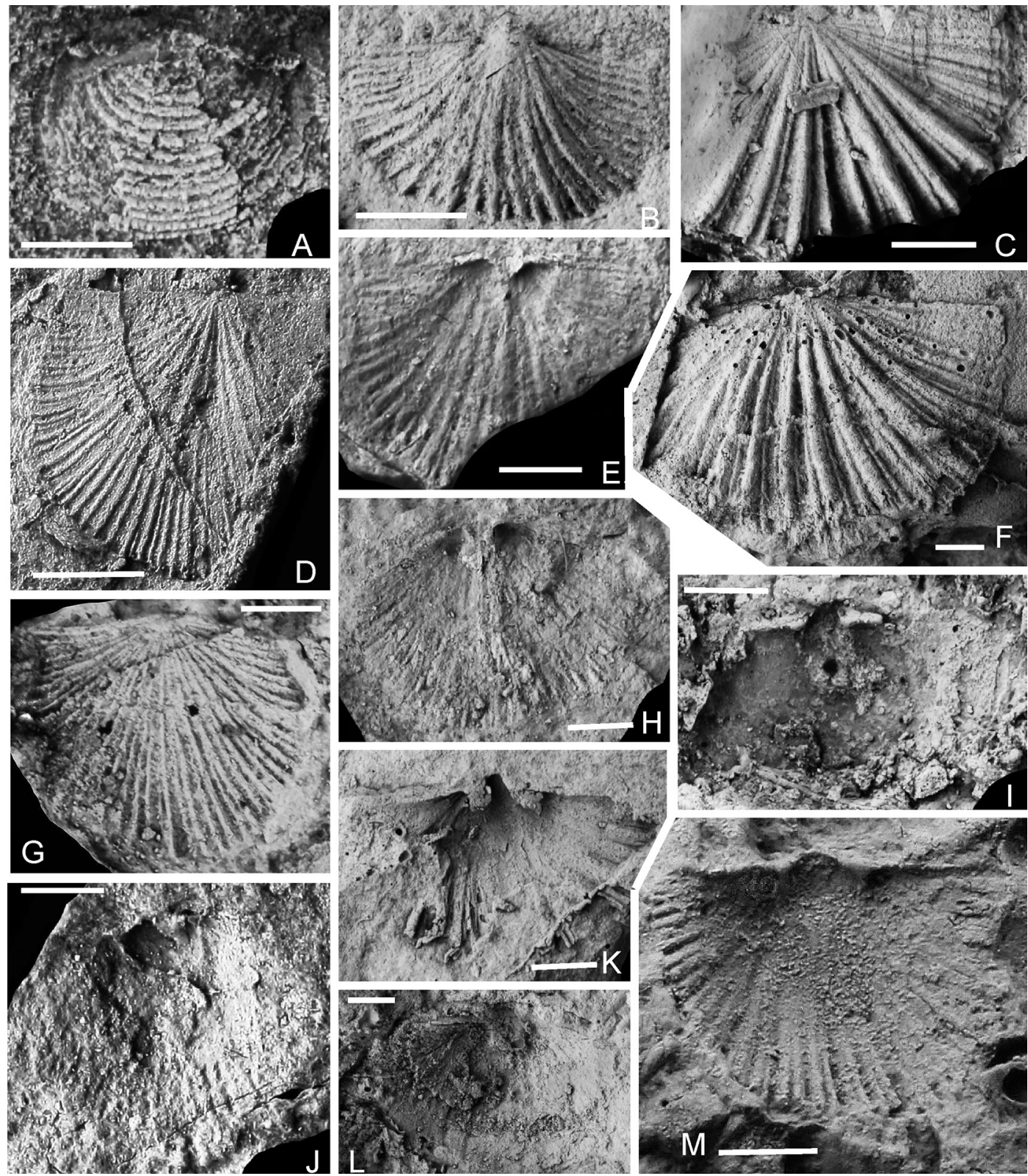

FIGURE 3. Brachiopods. A, QMF60316, Siphonotretidae indet., dorsal valve, internal mould. B, D, E, G, H, J, Orthide indet., QMF60317, latex cast from external mould of ventral valve: D, QMF60319, latex cast from external mould of dorsal valve; E, QMF60320, latex cast from internal mould of dorsal valve; G, QMF60322, latex cast from external mould of dorsal valve; H, QMF60323, latex cast from internal mould of dorsal valve; J, QMF60325, latex cast from internal mould of ventral valve. C, F, K, M, ?Phaceloorthis sp.: C, QMF60318, latex cast from external mould of dorsal valve; F, QMF60321, latex cast from external mould of ventral valve; K, QMF60326, latex cast from internal mould of ventral valve; M, QMF60328, latex cast from internal mould of ventral valve; I, L, Plectambonitid indet.; I, QMF60324, latex cast from internal mould of ventral valve; L, QMF60327, latex cast from internal mould of ventral valve. Scale bars $=1 \mathrm{~mm}$. 
Sericoidea sp. (Figure 4A-D)

Material. QMF60346-60348, three ventral valves.

Description. The three specimens are planar to very low convexity, thin shelled, diminutive, 2-3 mm long, 4-5 mm wide at hinge. Ornament sparsely finely costellate with additional costellae interpolated peripherally. Internal details poorly preserved on the sole available specimen (Figure 4C,D); muscle field bounded by a short divergent ridge extending from the hinge line; no myophragm apparent (although that may be due to inadequate preservation given the variability of the lithology).

Remarks. Lack of corresponding dorsal valves precludes meaningful comparison with other species of Sericoidea, particularly those known from the Macquarie Arc of central New South Wales.

Family LEPTELLINIDAE Ulrich \& Cooper, 1936 ?Leptellinid indet. (Figure 4F)

Material. QMF60350, internal mould of a ventral valve. Fortuitously preserved on the surface of this mould is a micromorphic (possibly juvenile) ventral valve.

Description. The larger ventral valve is strongly convex medially and flattened posterolaterally; transverse in outline, widest at the hinge line with width estimated at $10.2 \mathrm{~mm}$, length $6 \mathrm{~mm}$. Suggestion of a shallow anteromedian sulcus. Shell material presumably of moderate thickness as the external ornament is not reflected on the valve interior. Muscle field comparatively small and confined posteromedially. No obvious mantle canal impressions are preserved. Details of delthyrium obscured by matrix.

The micromorphic ventral valve (Figure 4F) may also represent a leptellinid. It is very slightly convex in profile, with a similar transverse outline to the valve in which it lies. Apart from a tiny, deeply incised muscle field confined to the delthryrial cavity, there are no obvious internal features of note.

Family PLECTAMBONITIDAE Jones, 1928

?Plectambonitid indet. (Figure 3I,L)

Material. QMF60324, 60327 both latex casts from internal moulds of ventral valves.

Description. One specimen (Figure 3L) shows a faint subperipheral rim and a short, low posteromedian platform supporting the muscle field. The other (Figure 3I) is more poorly preserved but also seems to display these features, together with an open delthyrium.

Remarks. The plectambonitoid Taphrodonta Cooper, 1956 is among several broadly related Ordovician genera that develop a subperipheral rim in the ventral valve and exhibit a rudimentary muscle field platform. In view of the lack of associated dorsal valves, further comparison is unwarranted and the Calliope material remains indeterminate.

Class RHYNCHONELLATA Williams, Carlson, Brunton, Holmer \& Popov, 1996

Order PROTORTHIDA Williams \& Harper, 2000 Family SKENIDIIDAE Kozlowski, 1929

Skenidioides Schuchert \& Cooper, 1931

Type species. Skenidioides billingsi Schuchert \& Cooper, 1931 from the Caradocian in Quebec; by original designation.

Remarks. Skenidioides is a long-ranging (Middle Ordovician-Early Devonian) genus with a cosmopolitan distribution. Most species are relatively small, widest at the hinge line and markedly transverse in outline with a planoconvex profile, often characterised by a median dorsal sulcus, and bear costellate ornamentation.

Skenidioides sp. indet. (Figure 4G-I)

Material. One dorsal valve internal mould (QMF60351) and two external moulds of a ventral valve (QMF60353) and dorsal valve (QMF60352).

Description. The internal mould, though not wellpreserved, shows what appears to be a very small notothyrial platform restricted to the posterior extremity of the dorsal valve. Neither a cardinal process nor a narrow median septum is evident, though a broad median ridge is present. Externally, what is presumed to be a juvenile ventral valve bears an accentuated median rib. The external mould of the dorsal valve displays fine growth lamellae crossed by closely spaced fine costellae.

Remarks. Similar ornamentation characterises the only species of Skenidioides, S. quondongensis Percival, 1991, to be described from the Late Ordovician (Katian) limestones of the Macquarie Arc of central New South Wales. The type material of $S$. quondongensis is silicified and hence relatively well preserved, displaying features of the cardinalia and median septum that are not evident in the specimens from central Queensland. 

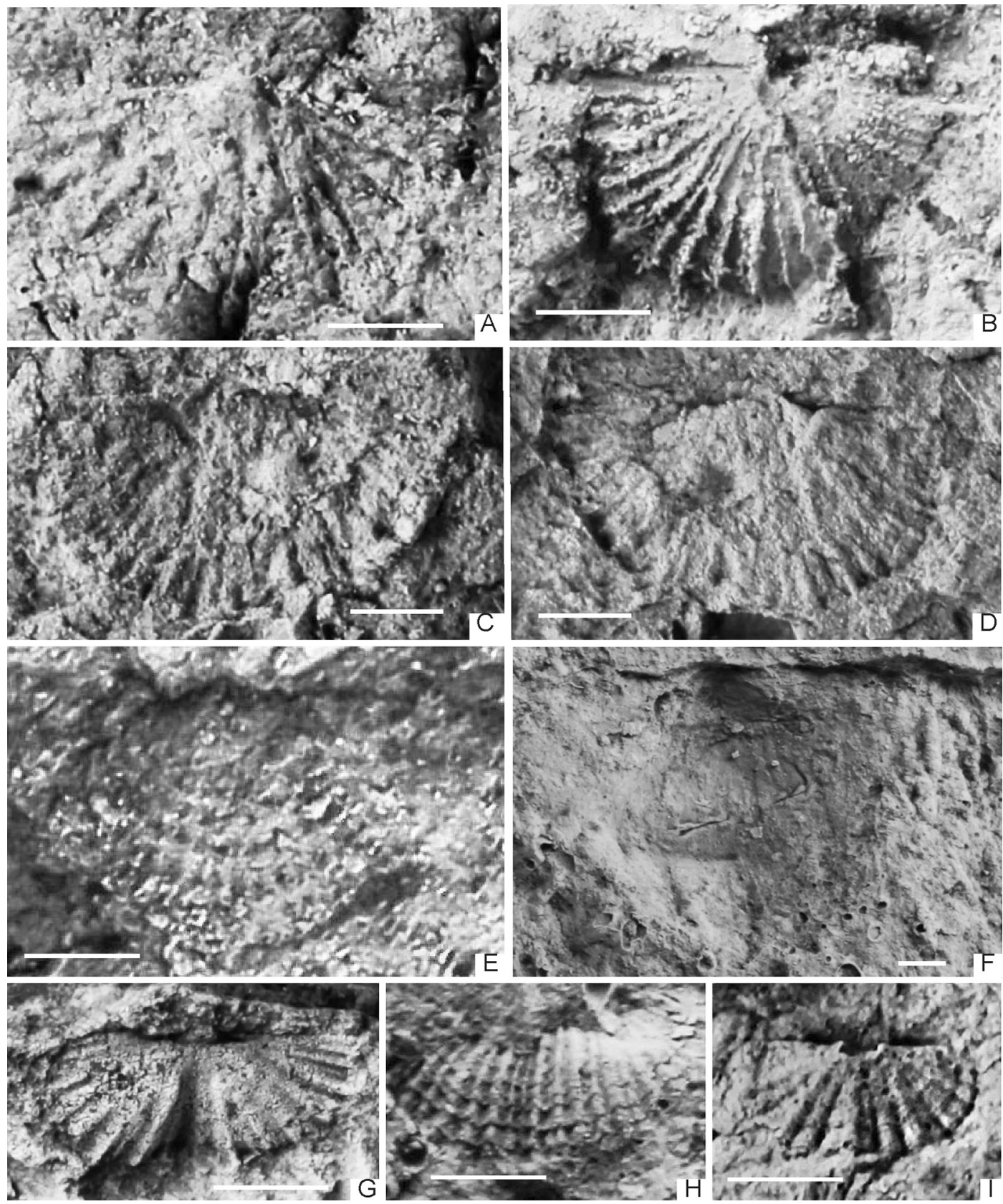

FIGURE 4. Brachiopods. A-D, Sericoidea sp.: A, QMF60346, latex replica from external mould of ventral valve, probably juvenile; B, QMF60347, latex replica from external mould of ventral valve; C, D, QMF60348, latex replica and internal mould of ventral valve; E, Siphonotretid indet. QMF60349, latex replica of external mould, valve indeterminate; F, ?Leptellinid indet. QMF60350, latex replica of internal mould of ventral valve. Note micromorphic ventral valve internal impressed on inner surface of valve. G-I, Skenidioides sp.: G, QMF60351, internal mould of dorsal valve; H, QMF60352, latex replica of external mould of dorsal valve; I, QMF60353, latex replica of external mould of ventral valve, probably a juvenile. Scale bars $=1 \mathrm{~mm}$. 
Order ORTHIDA Schuchert \& Cooper, 1932

Superfamily PLECTORTHOIDEA Schuchert \& LeVene, 1929

Family GIRALDIELLIDAE Williams \& Harper, 2000

Phaceloorthis Percival, 1991

Type species. Phaceloorthis decoris Percival, 1991 from the Katian Quondong Limestone, in the Macquarie Arc, central New South Wales; by original designation.

Remarks. Originally assigned to the Plectorthidae by Percival (1991), Phaceloorthis was provisionally classified as belonging to the Giraldiellidae established by Williams \& Harper (2000), with the qualification that it is more closely related to the stem group of both the Giraldiellidae and Plectorthidae. A fascicostellate (bundled) ornamentation is characteristic of several genera of the Giraldiellidae, but the robust shell that distinguishes Phaceloorthis from other members of that family is very distinct and is most similar to shell fragments preserved in the fault block on the Yarrol Fault.

?Phaceloorthis sp. (Figure 3C,F,?K,?M)

Material.QMF60318,60321, both external moulds of fragmentary dorsal and ventral valves, respectively. Tentatively assigned: QMF60326 (Figure 3K) and QMF60328 (Figure 3M), both ventral valve internal moulds.

Description. Shell fragments of robust valves with coarse fascicostellate external ornament, including a dorsal valve of low convexity with a slight median sulcus (Figure 3C) and a specimen interpreted as a ventral valve because of its greater overall convexity (Figure 3F).

Remarks. Two internal moulds of ventral valves may possibly be related to the exteriors described above, based on the internal reflections of the coarse fascicostellate ornament that become more accentuated towards the periphery of these valves (Figure $3 \mathrm{~K}, \mathrm{M}$ ). The shell material appears to be quite robust. The teeth in both specimens are stout (though not so well shown in Figure 3M due to the orientation of the hinge line) and supported on thin plates reaching the valve floor. These plates laterally delimit the muscle field which extends anteriorly for a short distance, estimated at no more than one-quarter of valve length. The only problem in attributing both these ventral valve interiors to ?Phaceloorthis is the delthyrium, which is open in Figure 3K (typical of Phaceloorthis) but apparently covered in part by a convex plate shown in Figure 3M. Closer examination of the latex mould at different orientations and lighting suggests in fact that this convex plate is likely an artefact of the process of replicating the specimen.

No corresponding valve interiors are currently known from this locality, and hence the genus identification, although likely, is tentative.

Orthide indet. (Figure 3B,D,E,G,H,J;

Figure 5A-C)

Material. QMF60317, 60319, 60320, 60322, 60323, 60325, 60354-60356.

Description. Valves with flattened ventribiconvex profile, dorsal valve bearing shallow and narrow median sulcus confined posteromedially; outline equidimensional but modified by broadly arcuate anterior margin; maximum width up to $7-8 \mathrm{~mm}$ at about midlength, only slightly greater than hinge width; hinge line straight with beak of ventral valve only projecting posteriorly in smallest specimens; ornament finely costellate, with additional costellae intercalated in anterior and anterolateral part of larger specimens; costellae predominantly straight except where recurved posterolaterally to become parallel to hinge line.

Ventral interior (Figures 3J, 5A): Muscle field extends to between one-quarter and one-fifth valve length, largely confined to shallow delthyrial cavity, bounded anteriorly by very low, curved ridge. No other details distinct.

Dorsal interior (Figure 3E,H): Cardinalia consist of a delicate ridgelike cardinal process flanked by and separate from small flared crural plates; cardinal process continuous with a very weak median septum extending to about mid-length. Adductor muscle scars apparently long, shallowly impressed adjacent to median septum. Mantle canal impressions not observed.

Remarks. This is the most common brachiopod in the faunal assemblage, and one of the largest. The shell is thin, with impressions of even the fine costellae visible on the internal surface of valves. No punctae are evident, although the preservation would not necessarily preserve such fine features if they were in fact present. There are no distinctive features that suggest a particular orthoid family, although the overall morphology (particularly the simple cardinal process) is consistent with that group. 

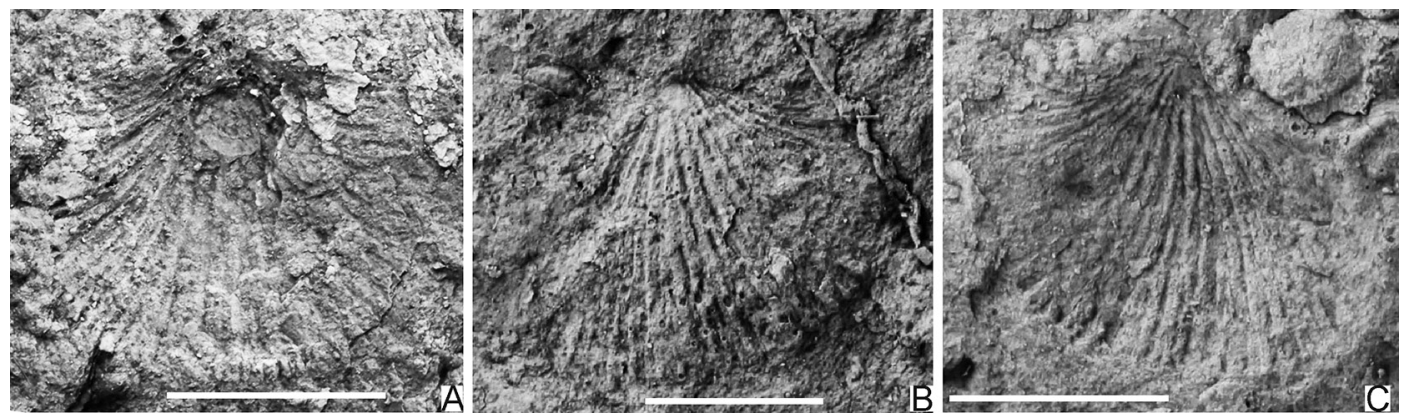

FIGURE 5. Brachiopods. A-C, Orthide indet.: A, QMF60354, internal mould of ventral valve; B, QMF60355, latex replica of ventral? valve external mould; C, QMF60356, latex replica of ventral valve external mould. Scale bars $=1 \mathrm{~mm}$.

\section{Phylum ARTHROPODA \\ Class TRILOBITA}

Suborder AGNOSTINA Salter, 1864

Family METAGNOSTIDAE Jaekel, 1909

Arthrorhachis Hawle \& Corda, 1847

Type Species. Battus tardus Barrande, 1846, by monotypy.

Remarks. Boundaries between Ordovician agnostid genera are difficult to define, and regular reshuffling of species by different authors is apparent (Nielsen, 1997). Generic discriminators often seem more reasonable as species discriminators, perhaps being attached to genera because the name is available and it is simpler to try to justify the name than to convince all readers of a synonymy. It is beyond the purpose of this paper to assess these generic taxa, so our assignment is made purely on the basis of comparison with previously named species and their current generic placement.

\section{Arthrorhachis sp. (Figure 6A)}

Material. QMF60335, an external mould of a cranidium.

Description. Cranidium $2 \mathrm{~mm}$ long by $1.5 \mathrm{~mm}$ wide. Border and border furrow approximately same length (sag.); border tapering in posterior half of cranidium. Glabella parallel-sided, with broadly rounded anterior, without transverse furrows, about 70 per cent cranidial length. Basal lobes present but indistinct.

Remarks. The single cranidium available is assigned to Arthrorhachis by comparison with Swedish specimens of the type species (Ahlberg, 1989, fig. 2).
Note that our specimen figured here is a latex cast from an external mould so features of the inner surface of the exoskeleton, seen on internal moulds, are not available. Ahlberg's (1989, fig. 2E) illustrated specimen appears identical with our specimen, but because we have only one cranidium and no pygidia we leave the specimen in open nomenclature.

\section{Suborder ILLAENINA Jaanusson in Harrington et al., 1959}

Family ILLAENIDAE Hawle \& Corda, 1847

\section{Illaenus Dalman, 1827}

Type Species. Entomostracites crassicauda Wahlenberg, 1818; by subsequent designation of Miller, 1889.

Remarks. Although effaced trilobites are notoriously hard to classify, and despite the poor state of preservation of the limited exoskeletal parts illustrated herein, we do make generic assignment based on close comparison with Illaenus sinensis Yabe in Yabe \& Hayasaka, 1920 from the Middle Ordovician of China (see Lu, 1975, pl. 31, fig. 6; Zhou et al., 1998, pl. 6) and the co-occurring I.cekovioides Zhou, Z. Y., Yin \& Zhou, Z. Q., 2014 (see Zhou et al. 2014, fig. 14). Zhou et al. (2014) assigned these species to Jaanusson's (1957) Illaenus sarsi Species Group based, principally, on the bicuspid anterior margin of the pygidial doublure. This part of the exoskeleton (i.e. the abmarginal edge of the pygidial doublure) is not evident on these Queensland specimens. The rounded genal angle, short, narrow pygidial axis, nature of the pygidial facet, along with overall shape and convexity, coincide closely with these Chinese species. 


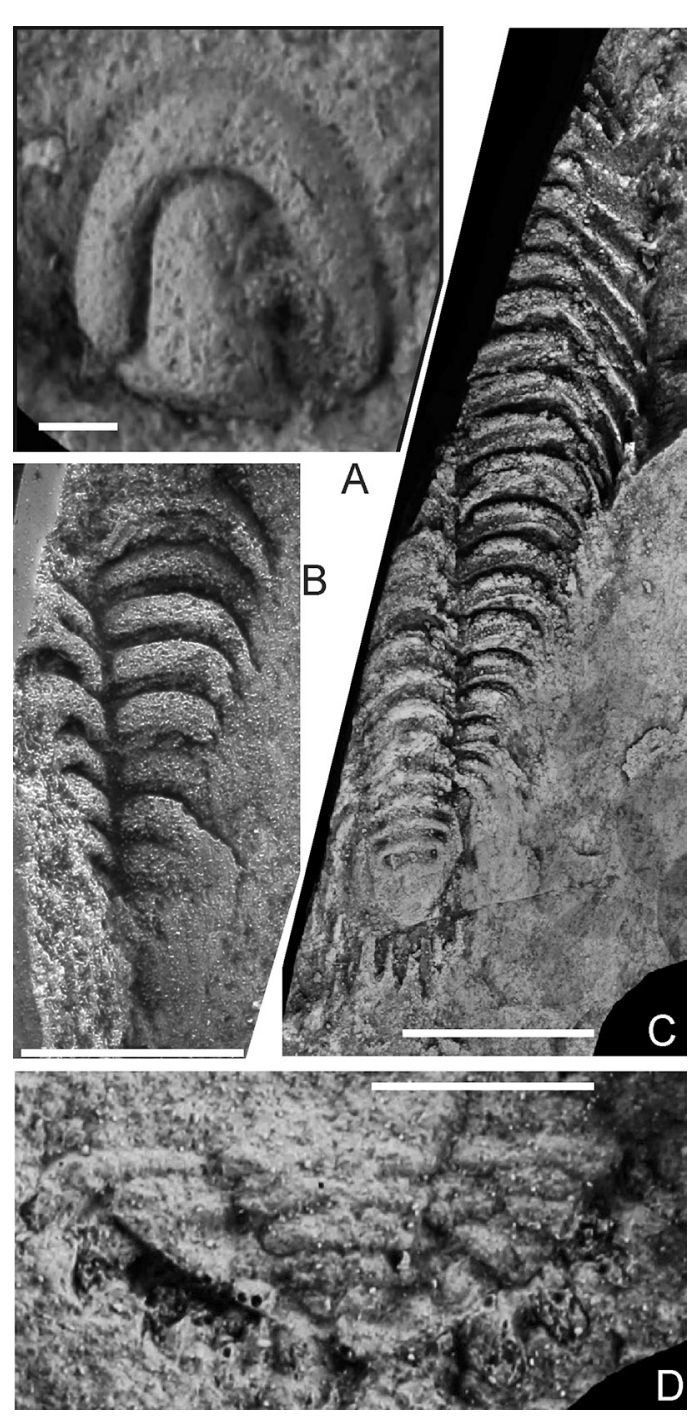

FIGURE 6. Trilobites. A, Arthrorhachis sp., QMF60335, latex cast of cranidium. Scale bar $=1 \mathrm{~mm}$. B, C, Pliomerid indet. 1. QMF60336: B, latex cast from external mould from part of thorax in $\mathrm{C}$; $\mathrm{C}$, internal mould of incomplete thoracopygon showing pygidium plus partial thorax with more than 12 segments. D, Pliomerid indet. 2. QMF60337, pygidium, latex cast from external mould. Scale bars $=5 \mathrm{~mm}$.

Illaenus sp. (Figure 7B-H)

Material. QMF60330-60334, one badly damaged librigena and five pygidia.

Description. Librigena with smooth lateral margin and rounded genal angle lacking any genal spine or sharp angle; eye relatively small, with steep eye socle.

Pygidium smooth, gently convex, subsemicircular, almost twice as wide as long. Axis short, narrow, subtriangular, 20-25\% of pygidial length (though $38 \%$ in one specimen [Figure 7C]), elevated above the pleural areas anteriorly but descending to the rear. Axial furrows poorly impressed or simply a change of slope. Inter-ring furrows not evident. Pleural areas without any furrows, except for broad, shallow anterior pleural furrow, most obvious adjacent to fulcrum. Facet small, transversely oblique, subtriangular and steep. Doublure wide, extending to posterior tip of axis in one specimen (Figure 7C).

Remarks. With the relatively poor preservation and without a cranidium or clear ventral morphology we are forced to leave this material in open nomenclature. The geographically closest described species of the genus is Eastonillaenus incertus (Webby, 1973) from the Upper Ordovician Ballingoole Formation in central western New South Wales, but that species is not closely related, being distinguished by its longer pygidial axis that is wider at the pygidial anterior and narrower pygidial doublure. Webby (1973) did separate one pygidium because it had a narrower axis at the anterior margin and a broader doublure, so it could be considered more like the Illaenus sp. described herein.

It is not certain that all these pygidia represent a single species. The specimen in Figure 7C is more equidimensional than the other larger, more transverse pygidia, but this, in itself, is not sufficient to be sure of species differentiation.

\section{Suborder CHEIRURINA Harrington \& Leanza, 1957 Family PLIOMERIDAE Raymond, 1913}

Pliomerid sp. 1 (Figure 6B,C)

Material. QMF60336, an incomplete thoracopygon.

Description. Thorax of at least 16 segments, tapering to posterior, with convex axis apparently of uniform width as pleural areas decrease in width posteriorly. Each segment with prominent, convex, pleural band and low, short (exsag.), articulating flanges along posterior margin. Pygidium (excluding marginal spines) subquadrate to subpentagonal with broadly rounded posterior; marginal spines in four pairs, posteriorly directed, with shortest pair the most posterior; axis of four rings plus a short, rounded terminus; rings relatively short in internal mould. 

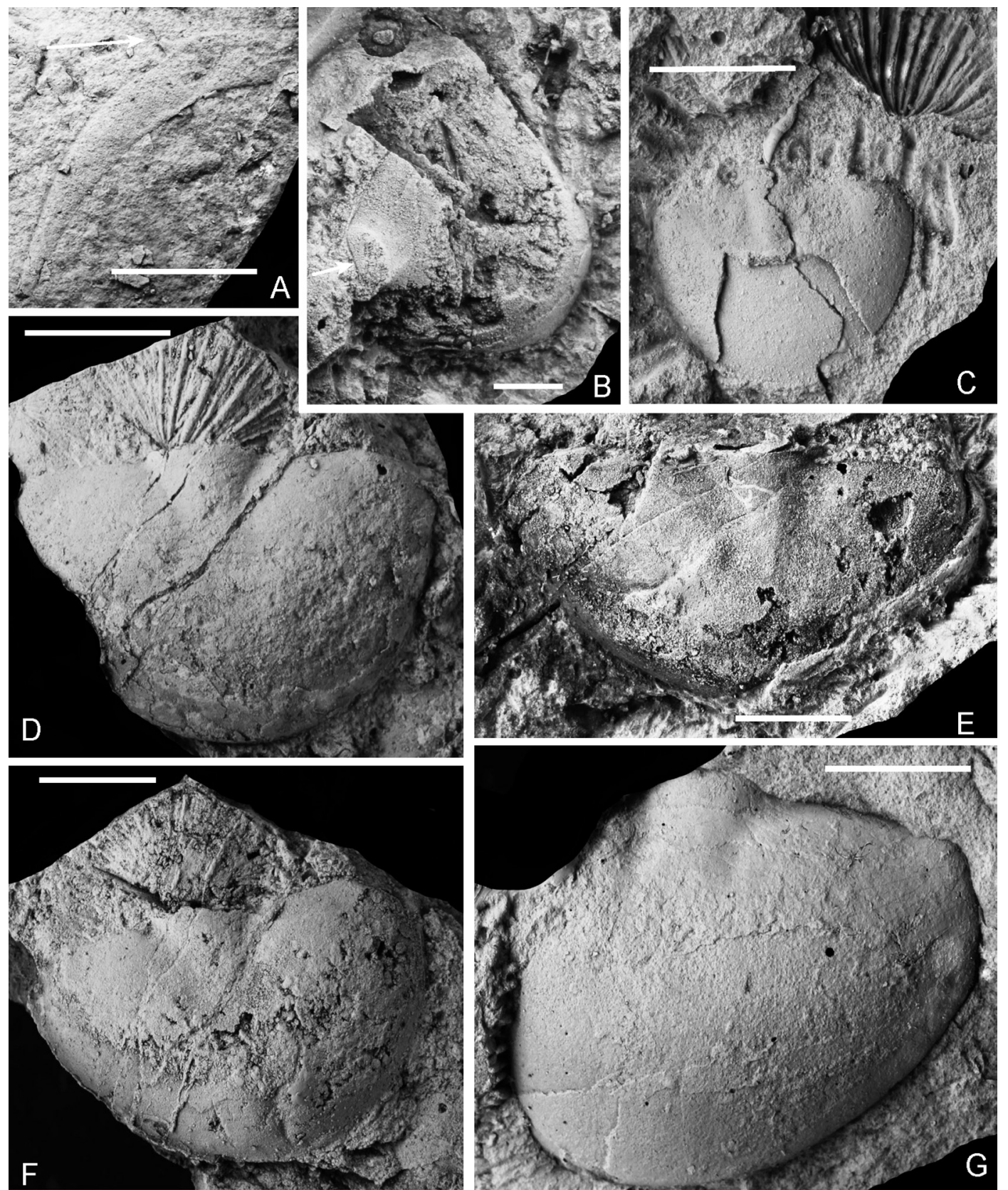

FIGURE 7. Trilobites. A, Cheirurid indet., QMF60329, latex cast of partial thoracic segment with prominent spinelike articulating process (arrowed). B-G, Illaenus sp.: B, QMF60330, badly damaged librigena showing position of the palpebral lobe (arrowed) and non-spinose, rounded, genal angle; C, QMF60331, internal mould of small pygidium with very wide doublure; brachiopod is ?Phaceloorthis sp.; D, F, QMF60332, latex cast from external mould and internal mould of partial pygidium showing short triangular axis and with brachiopod, Sericoidea sp., lying beneath articulating halfring; E, QMF60333, damaged internal mould of pygidium; G, QMF60334, latex cast of partial pygidium. Scale bars $=5 \mathrm{~mm}$. 
Remarks. The low ledge along the posterior margin of each thoracic segment is interpreted as an articulating flange by comparison with other pliomerids such as Hintzeia McAdams \& Adrain, 2011a (see McAdams \& Adrain, 2011a, pl. 8). It appears to extend beyond the fulcrum as it does in material figured by McAdams \& Adrain (2011a). Slight forward rotation of the segments conceals the anterior margin of all segments where a similar articulating flange could be expected.

Taxonomic placement of this specimen is impossible, and none of the following comments are intended to imply relationship at generic level but merely to show some shared pliomerid family characters. Members of the Pliomeridae have up to 19 thoracic segments, and a specimen of Hintzeia parafirmimarginis McAdams \& Adrain, 2011a (see McAdams \& Adrain, 2011a, pl. 8) has 15 thoracic segments that compare closely with those in the specimen described here. However, the pygidium described here appears to be narrower and have four pairs of longer, more slender, marginal spines, features of Panisaspis McAdams \& Adrain, 2011b evident, for example in P. quattuor (Hintze, 1953) (see McAdams \& Adrain, 2011b, pls 27, 31, 32).

Externally the pygidial axial rings may be longer (sag.) than in the internal mould, a significant difference being inferred by comparison with Protopliomerops lindneri Jell, 1985. In that figure the difference between internal and external appearances of the axial rings is quite obvious and may be inferred to represent pliomerids in general, the family being known to have relatively thick carapaces.

Pliomerid sp. 2 (Figure 6D)

Material. QMF60337, an external pygidial mould.

Description. Pygidium subtriangular, $5 \mathrm{~mm}$ long and $9 \mathrm{~mm}$ wide, with five pairs of stout marginal spines directed posteriorly; axis triangular, tapering strongly to rear, almost half pygidial width anteriorly, of five rings plus tiny terminal axial piece; pleural areas crossed by five prominent pleural bands extending into the marginal spines and defined by deep pleural furrows.

Remarks. Among Australian pliomerids, Hintzeia sp. undet. (see Laurie \& Shergold, 1996, pl. 6, figs 1-11) from the Bendigonian Emanuel Formation in the
Canning Basin of Western Australia has pygidia that match fairly closely with this Queensland specimen, allowing for the extremely imperfect preservation of the latter, but beyond showing a pliomerid affinity this comparison is not meant to imply close relationship.

Order PHACOPIDA Salter, 1864

Suborder CHEIRURINA Salter, 1864

\section{Thoracic segment fragment (Figure 7A)}

Material. QMF60329, a small, left pleural fragment of thoracic segment.

Description. Inner (or articulated) pleural area with parallel anterior and posterior margins, without any furrows. Fulcral process prominent, tapering anterolaterally but with flattened extremity. Outer (or free) pleural area flat, curving and tapering posterolaterally to rounded tip (as preserved), without a pleural furrow.

Remarks. The distinctive feature of this specimen that allows placement in the Cheirurina is the very prominent, almost spine-like fulcral process and flattened, posteriorly sweeping free pleura. Comparison is drawn with Nieszkowskia jakei Edgecombe et al., 1999 (see Edgecombe et al., 1999, pl. 3, figs 7, 8) which has the spine-like fulcral processes of comparable proportion to that on the thoracic segment described here, and with Holia secristi Whittington \& Evitt, 1953 (see Whittington \& Evitt, 1953, pl. 31, figs 20, 21, 31, 34).

\section{Phylum ECHINODERMATA \\ Class CRINOIDEA}

Stem ossicles indet. (Figure 8A-E)

Material. QMF60338-60342, moulds of crinoid stem ossicles chosen as representing a much larger number in the collection from this site.

Description. Figure 8A shows the articular facet of a pentameric stem, about $1.5 \mathrm{~mm}$ in diameter, with a very large pentagonal lumen occupying more than half ossicle diameter.

Figure $8 \mathrm{~B}$ is of a holomeric ossicle, also about $1.5 \mathrm{~mm}$ in diameter, with a large pentalobate lumen occupying just over half ossicle diameter.

Figure $8 \mathrm{C}$ is a more common form of articular surface having a relatively small circular lumen, narrow areola and wider peripheral crenularium. 


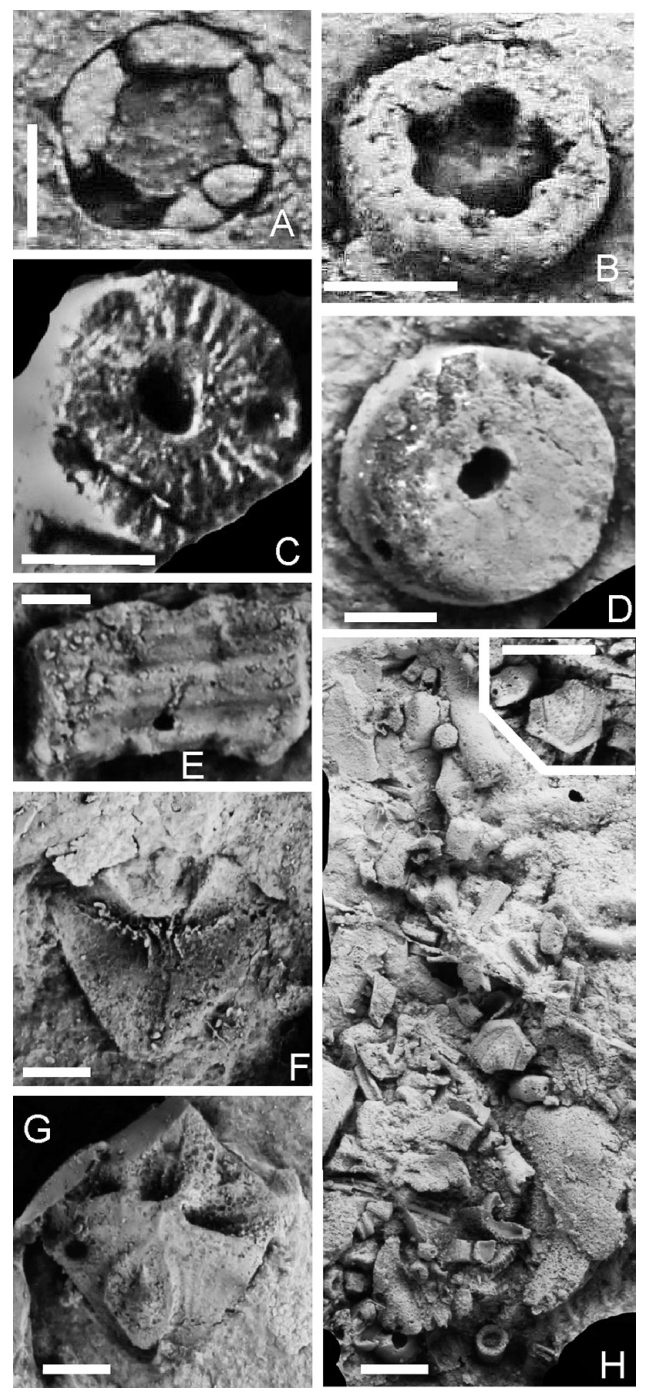

FIGURE 8. Crinoid stem ossicles and brachial plates. A, QMF60338, pentameric stem ossicle, end view. B, QMF60339, stem ossicle, viewing circular section and large pentalobate lumen. C, QMF60340, stem ossicle, end view with smooth circular face and small-diameter lumen. D, QMF60341, stem ossicle, end view showing prominent crenularium occupying entire radius except for the lumen. E, QMF60342, stem ossicle in lateral view, showing deep longitudinal grooves. F, QMF60343, articular face of brachial plate. G, QMF60344, articular face of brachial plate. H, QMF60345, accumulation of small, dissociated echinoderm plates (inset: an enlargement of single plate in centre of main image). Scale bars $=0.5 \mathrm{~mm}$ in $\mathrm{A}$ and $\mathrm{B} ;=1 \mathrm{~mm}$ in $\mathrm{C}-\mathrm{H}$ and $\mathrm{H}$ inset.
In Figure 8D the articular facet is a plane surface with small lumen and no crenularium. This type of facet indicates synostosial articulation, possibly totally inflexible.

Figure $8 \mathrm{E}$ is a lateral view of a tiny, about $0.3 \mathrm{~mm}$ in diameter, elongate (about $3.5 \mathrm{~mm}$ long) stem ossicle with a tetragonal, almost cruciform cross-section.

Remarks. A variety of stem ossicles are preserved with this fauna, and although not definitive for age determination, they are, collectively, more in accord with an Ordovician age than any other age. The two ossicles in Figures 8A and 8B, each of very small diameter for crinoid stems and large lumens compared to stem diameter, have much more in common with Cambrian and Ordovician echinoderms than later forms. Pentameric stems, as in Figure 8A, occur in early crinoids (Guensburg et al., 2016). Ossicles with articular facets like that in Figure 8C are known through most of the Palaeozoic - Ordovician to Permian. They provide no assistance in dating the fauna. Donovan (1989) noted that synostosial articulating facets, as in Figure 8D, are rare, restricted to some early Ordovician forms and recent isocrinids, the latter having evolved this feature (more correctly called cryptosymplexy in that group) independently. We can find no ossicles comparable to the one in Figure $8 \mathrm{E}$ having been previously described in the literature.

This array of stem ossicle types is more suggestive of an Ordovician age than any other. Donovan (1989, p. 252) noted that "Crinoid columnal evolution in the Ordovician included the development of many novel morphologies, often utilising unusual symmetry elements. These represent 'experiments' in morphological variation which developed early in the history of the crinoids. Few of these unusual morphologies survived into the Silurian and after." Taking this observation into consideration, with the stem ossicle morphologies noted above they most probably represent an Ordovician fauna.

Brachial plates indet. (Figure 8F,G)

Material. QMF60343, 60344, external moulds of two dissociated plates.

Remarks. We interpret the exposed surface of these two plates as the articular surface of brachials dissociated from crinoid arms, by comparison with 
the cross-sections of Ordovician cyathocrinine and disparid arms illustrated by Guensburg et al. (2016, fig. $7 \mathrm{~B}, \mathrm{C}_{2}$ ). The upper part of the cross-section is well illustrated by Guensburg et al. (2016), showing floor plates and cover plates, but in these Queensland specimens the upper plates have been dislodged and are damaged to a degree. However, in Figure 8F the floor of the ambulacral groove is well shown. In Figure $8 \mathrm{G}$ several pockets on the crest of the brachial are difficult to interpret but may be associated with podial pores, although they are larger and more prominent than those illustrated by Guensburg et al. (2016, fig. 7B). Their interpretation, and indeed the identity of this plate, are very tentative.

Thecal plate indet. (Figure $8 \mathrm{H}$ )

Material. QMF60345, external mould of an accumulation of tiny, mostly echinodermal plates.

Remarks. This tiny, damaged plate, less than $1 \mathrm{~mm}$ in largest dimension, was probably hexagonal and most likely a tegminal plate from a crinoid. It is not identifiable with any confidence but is the only discernible plate in an accumulation of very small, probably mostly echinodermal plates.

\section{Age}

The main aim of this paper is to confirm the previously reported Ordovician age of this fauna. The only indications of its age come from the trilobites and brachiopods. The sponge spicules and assorted echinoderm plates are not age diagnostic, though they are more consistent with an Ordovician age than any other. Among the trilobites, Arthrorhachis sp., the single agnostoid cranidium, is most instructive since that genus is restricted to the Ordovician (Shergold \& Laurie, 1997). Its occurrence constrains the age of the fauna between the Tremadocian as the oldest and Hirnantian as the youngest possible ages. Illaenus is only known from the Ordovician, and species with which Illaenus sp. compares most closely (short, narrow, triangular pygidial axis) mostly derive from the Middle Ordovician. Pliomerid trilobites are not known outside the Ordovician. The Cheiruridae, of which only a partial thoracic segment is described, ranges through the Ordovician to Devonian. Thus, the trilobites clearly indicate an age within the Ordovician, most probably Middle or Late Ordovician.

The brachiopods are at best only able to be assigned at genus level, due to inadequate preservation and the scarcity of diagnostic valve interiors. Nevertheless, their age is undoubtedly Ordovician with a definite Katian (Late Ordovician) aspect. The dominant forms are orthides of the superfamily Plectorthoidea, of which two types are recognisable. Rare but distinctive because of their fascicostellate ornament are robust shells resembling Phaceloorthis (originally described from the Late Ordovician island arc limestones of central New South Wales). More commonly present is a medium-sized orthoid with a finely costellate ornament, the ventral valves of which have a profile of very low convexity. This genus is unable to be identified with any certainty. Skenidioides, a diminutive protorthide characterised by a strongly convex ventral valve and a dorsal valve with a pronounced median sulcus, is relatively long ranging, from Ordovician to Devonian. Two strophomenides are recognised; one internal mould of a strongly convex ventral valve with a small, deeply inset muscle field is probably a leptellinid plectambonitoid, but lacks a corresponding dorsal valve required to confirm the genus. More common (and most useful for the age determination) are valves of Sericoidea, a diminutive plectambonitoid known from the Macquarie Arc of central New South Wales in deeper-water clastic rocks of Katian age. The other brachiopod identified is a siphonotretide lingulate, which although not diagnostic of a precise age, is comparable to genera of this group described from the Upper Ordovician rocks from the Macquarie Arc in New South Wales and the Broken River Province, west of Townsville in central Queensland.

\section{Acknowledgements}

We are grateful to Paul Blake, who discovered the first Ordovician fossils in this area and made them available for study. We thank Mr Ken Anderson for access to the site and hospitality on his property. We thank David Holloway for careful review of sections of the paper relating to trilobite systematics. Journal reviews by Yves Candela and two anonymous referees improved the final paper, and we appreciate their input. Ian Percival publishes with permission of the Executive Director of the Geological Survey of New South Wales. This is a contribution to IGCP project 735 'Rocks and the Rise of Ordovician Life'. 


\section{Literature Cited}

Ahlberg, P. (1989). Agnostid trilobites from the Upper Ordovician of Sweden and Bornholm, Denmark. Bulletin of the Geological Society of Denmark, 37, 213-226. https://doi.org/10.37570/bgsd-1988-37-17

Barrande, J. (1846). Notice préliminaire sur le systême Silurien et les Trilobites de Bohême. Hirschfeld, 1-97. https://doi.org/10.5962/bhl.title.9142

Birch, W. D. (Ed.). (2003). Geology of Victoria. Geological Society of Australia, Special Publication, 23, $1-842$.

Blake, P. R. (2013). Calliope Province. In P. A. Jell (Ed.), Geology of Queensland (pp. 311-317). Geological Survey of Queensland.

Botting, J. P. (2005). Ordovician sponges from the Llandegley Rocks lagerstätte, Wales. Palaeontology, 48, 577-617. https://doi.org/10.1111/j.1475-4983.2005.00470.x

Botting, J. P. (2021). Hexactins in the 'protomonaxonid' sponge Choiaella and proposal of Ascospongiae (class nov.) as a formal replacement for the Protomonaxonida. Bulletin of Geosciences, 96(3), 1-13. https://doi.org/10.3140/bull.geosci.1823

Botting, J. P., \& Muir, L. M. (2018). Early sponge evolution: A review and phylogenetic framework. Palaeoworld, 27, 1-29. https://doi.org/10.1016/j.palwor.2017.07.001

Botting, J. P., Muir, L. M., \& Lin, J. P. (2013). Relationships of the Cambrian Protomonaxonida (Porifera), Palaeontologia Electronica, 16(2), 1-23. palaeo-electronica.org/content/2013/421-protomonaxonidrelationships https://doi.org/10.26879/339

Candela, Y. (2011). A systematic revision of the Ordovician plectambonitoidean brachiopods Chonetoidea and Sericoidea. Journal of Systematic Palaeontology, 9(4), 499-522. https://doi.org/10.1080/1477201 9.2010 .528457

Cawood, P. (1976). Cambro-Ordovician strata, northern New South Wales. Search, 7, 378-379.

Cocks, L .R. M., \& Rong Jia-yu. (2000). Order Strophomenida. In R. L. Kaesler (Ed.), Treatise on Invertebrate Paleontology, Part H, Brachiopoda, Revised (Vol. 2) (pp. 216-348). Geological Society of America and University of Kansas.

Cooper, G. A. (1956). Chazyan and related brachiopods. Smithsonian Miscellaneous Collections, 127(1), $1-1024 ; 127(2), 1025-1245$.

Dalman, J. W. (1827). Om Palaeaderna eller de så kallade Trilobiterna. Kongliga Svenska VetenskapsAkademiens Handlingar, 1826(2), 113-162, 226-294.

Dixon, O. A., \& Jell, J. S. (2012). Heliolitine tabulate corals from Late Ordovician and possibly early Silurian allochthonous limestones in the Broken River Province, Queensland, Australia. Alcheringa: An Australasian Journal of Palaeontology, 36, 1-30. https://doi.org/10.1080/03115518.2011.582807

Donchak, P. J. T., Purdy, D. J., Withnall, I. W., \& Jell, P. A. (2013). The New England Orogen. In P. A. Jell (Ed.), Geology of Queensland (pp. 305-472). Geological Survey of Queensland.

Donovan, S. K. (1989). The significance of the British Ordovician crinoid fauna. Modern Geology, 13, 243-255.

Edgecombe, G. D., Chatterton, B. D. E., Vacari, N. E., \& Waisfeld, B. G. (1999). Ordovician cheirurid trilobites from the Argentine Precordillera. Journal of Paleontology, 73(6), 1155-1175. https://doi. org $/ 10.1017 / \mathrm{S} 0022336000031048$

Fergusson, C. L., \& Henderson, R. A. (2015). Early Palaeozoic continental growth in the Tasmanides of northeast Gondwana and its implications for Rodinia assembly and rifting. Gondwana Research, 28(3), 933-953. https://doi.org/10.1016/j.gr.2015.04.001

Fergusson, C. L., \& Withnall, I. W. (2012). Fork Lagoons Subprovince. In P. A. Jell (Ed.), Geology of Queensland (pp. 128-130). Geological Survey of Queensland.

Finks, R. M., \& Rigby, J. K. (2004). Paleozoic demosponges. In R. L. Kaesler (Ed.), Treatise on Invertebrate Paleontology, Part E, Porifera, Revised (Vol. 3) (pp. 9-173). Geological Society of America and University of Kansas.

Fordham, B. G. (2012). Appendix 2 - Ordovician-lower Carboniferous conodont dating. Queensland Geology, 13, 567-585. 
Glen, R. A. (2005). The Tasmanides of eastern Australia. Geological Society of London, Special Publication, 246, 23-96. https://doi.org/10.1144/GSL.SP.2005.246.01.02

Glen, R. A. (2013). Refining accretionary orogen models for the Tasmanides of eastern Australia. Australian Journal of Earth Sciences, 60(3), 315-370. https://doi.org/10.1080/08120099.2013.772537

Gorjansky, V. Y., \& Popov, L. E. (1985). Morfologiya, sistematicheskoe polozhenie i proiskhozhdenia bezzamkovykh brakhiopod s karbonatnoj rakovinoj [The morphology, systematic position, and origin of inarticulate brachiopods with carbonate shells]. Paleontologicheskii Zhurnal, 1985, 3-13.

Guensburg, T. E., Blake, D. B., Sprinkle, J., \& Mooi, R. (2016). Crinoid ancestry without blastozoans. Acta Palaeontologica Polonica, 61, 253-266. https://doi.org/10.4202/app.00211.2015

Hadding, A. (1913). Undre Dicellograptusskiffern i Skåne jämte några därmed ekvivelenta bildningar. Lund Universitets Årsskrift (new series), 9(2) (15), 1-90.

Harrington, H. J., \& Leanza, A. F. (1957). Ordovician trilobites of Argentina. Department of Geology, University of Kansas, Special Publication, 1, 1-276.

Harrington, H. J., Henningsmoen, G., Howell, B. F., Jaanusson, V., Lochman-Balk, C., Moore, R. C., Poulsen, C., Rasetti, F., Richter, E., Richter, R., Schmidt, H., Sdzuy, K., Struve, W., Tripp, R., Weller, J. M., \& Whittington, H. B. (1959). Systematic descriptions. In R. C. Moore (Ed.), Treatise on Invertebrate Paleontology, Part O, Arthropoda 1, (pp. 170-539). Geological Society of America and University of Kansas. https://doi.org/10.17161/dt.v0i0.5605

Havlíček, V. (1961). Rhynchonelloidea des böhmischen älteren Paläozoikums (Brachiopoda). Rozpravy Ústredního ústavu geologického, 27, 1-211.

Hawle, I., \& Corda, A. J. C. (1847). Prodrom einer Monographie der böhmischen Trilobiten. Abhandlungen Kongligischen Böhemischen Gesellschaft der Wiossenschaften, V. Folge, 5(5), 1-176.

Henderson, R. A. (1983). Early Ordovician faunas from the Mount Windsor Subprovince, northeastern Queensland. Memoirs of the Association of Australasian Palaeontologists, 1, 145-175.

Hintze, L. F. (1953). Lower Ordovician trilobites from western Utah and eastern Nevada. Utah Geological and Mineralogical Survey Bulletin, 48, 1-249.

Jaanusson, V. (1957). Unterordovizische Illaeniden aus Skandinavien. Bulletin of the Geological Institute, University of Uppsala, 37, 79-165.

Jaekel, O. (1909). Über die Agnostiden. Zeitschrift der Deutschen Geologischen Gesellschaft, 61, 380-401.

Jell, P. A. (1985). Tremadoc trilobites of the Digger Island Formation, Waratah Bay, Victoria. Memoirs of the Museum Victoria, 46, 53-88. https://doi.org/10.24199/j.mmv.1985.46.03

Jell, P. A., \& Cook, A. G. (2011). Musaspongia amnicola, a new sponge from the Lower Devonian of Victoria. Proceedings of the Royal Society of Victoria, 123(2), 136-140.

Jessop, K., Daczko, N. R., \& Piazolo, S. (2019). Tectonic cycles of the New England Orogen, eastern Australia: A review. Australian Journal of Earth Sciences, 66, 459-496. https://doi.org/10.1080/ 08120099.2018.1548378

Jones, O. T. (1928). Plectambonites and some allied genera. Memoirs of the Geological Survey of Great Britain, Palaeontology, London, 1, 367-527.

Kolobova, I. M., \& Popov, L. E. (1986). K paleontologitscheskoi kharakteristike anderkenskogo gorizonta srednego ordovika v Chu-Iliyskikh Gorakh (Juzhnyi Kazakhstan). Ezhegodnik Vsesojuznogo Paleontologicheskogo Obshchestva, 29, 246-261.

Kozlowski, R. (1929). Les brachiopodes gotlandiens de la Podolie polonaise. Palaeontologia Polonica, $1,1-254$.

Kuhn, O. (1949). Lehrbuch der Paläozoologie. E. Schweizerbart.

Kutorga, S. S. (1848). Ueber die Brachiopoen-Familie der Siphonotretaceae. Russisch-Kaiserliche Mineralogische Gesellschaft zu St. Petersbourg, Verhandlingen, 1847, 250-286.

Laurie, J. R., \& Shergold, J. H. (1996). Early Ordovician trilobite taxonomy and biostratigraphy of the Emanuel Formation, Canning Basin, Western Australia. Palaeontographica A, 240, 1-144.

Lindström, M. (1953). On the lower Chasmops Beds in the Fågelsång district (Scania). Geologiska Föreningens i Stockholm Förhandlingar, 75(2), 125-148. https://doi.org/10.1080/11035895309454168 
Lu, Y. H. (1975). Ordovician trilobite faunas of central and southwestern China. Palaeontologia Sinica, $152,1-463$.

McAdams, N. E. B., \& Adrain, J. M. (2011a). Systematics of the Lower Ordovician pliomerid trilobite Hintzeia, with species from the Great Basin, western USA. Zootaxa, 2910, 1-45. https://doi. org/10.11646/zootaxa.2910.1.1

McAdams, N. E. B., \& Adrain, J. M. (2011b). Panisaspis, a new genus of pliomerid trilobites from the Lower Ordovician (Ibexian; Tulean and Blackhillsian) of the Great Basin, western USA. Zootaxa, 2969, 1-68. https://doi.org/10.11646/zootaxa.2969.1.1

Miller, S. A. (1889). North American geology and palaeontology for the use of amateurs, students, and scientists. Western Methodist Book Concern. https://doi.org/10.5962/bhl.title.40666

Murray, C. G., Blake, P. R., Crouch, S. B. S., Hayward, M. A., Robertson, A. D. C., \& Simpson, G. A. (2012). Geology of the Yarrol Province central coastal Queensland. Queensland Geology, 13, 1-658.

Nielsen, A. T. (1997). A review of Ordovician agnostid genera (Trilobita). Transactions of the Royal Society of Edinburgh: Earth Sciences, 87, 463-501. https://doi.org/10.1017/S0263593300018150

Öpik, A. A. (1934). Über die Klitamboniten. Tartu Ulikooli Geoloogia-Instituudi Toimestuesed Acta et Commentationes Universitatis Tartuensis, 39, 1-239.

Packham, G. H. (Ed.). (1969). The Geology of New South Wales. Journal of the Geological Society of Australia, 16, 1-654. https://doi.org/10.1080/14400956908527964

Palmieri, V. (1978). Late Ordovician conodonts from the Fork Lagoons beds, Emerald area, central Queensland. Geological Survey of Queensland Publication, 369, 1-31.

Percival, I. G. (1979). Late Ordovician articulate brachiopods from Gunningbland, central western New South Wales. Proceedings of the Linnean Society of New South Wales, 103, 175-187.

Percival, I. G. (1991). Late Ordovician articulate brachiopods from central New South Wales. Memoirs of the Association of Australasian Palaeontologists, 11, 107-177.

Percival, I. G., Quinn, C. D., \& Glen, R. A. (2011). A review of Cambrian and Ordovician stratigraphy in New South Wales. Quarterly Notes Geological Survey of New South Wales, 137, 1-39.

Raymond, P. E. (1913). A review of the species which have been referred to the genus Bathyurus. Bulletin of the Victoria Memorial Museum, 1, 51-80. https://doi.org/10.4095/104944

Salter, J. W. (1864). A monograph of the British trilobites. Part 1. Palaeontographical Society, London, Monograph, 1862, 1-80. https://doi.org/10.1080/02693445.1864.12113212

Schuchert, C., \& Cooper, G. A. (1931). Synopsis of the brachiopod genera of the suborders Orthoidea and Pentameroidea, with notes on the Telotremata. American Journal of Science (series 5), 22, 241-255. https://doi.org/10.2475/ajs.s5-22.129.241

Schuchert, C., \& Cooper, G. A. (1932). Brachiopod genera of the suborders Orthoidea and Pentameroidea. Memoirs of the Peabody Museum of Natural History, 4(1), 1-270. https://doi.org/10.5962/bhl.title.5732

Schuchert, C., \& LeVene, C. M. (1929). Brachiopoda (Generum et Genotyporum Index et Bibliographia). In J. F. Pompeckj (Ed.), Fossilium Catalogus, I: Animalia, part 42 (pp. 1-140). W. Junk.

Shergold, J. H., \& Laurie, J. R. (1997). Suborder Agnostina Salter, 1864. In R. L. Kaesler (Ed.), Treatise on Invertebrate Paleontology: Part O. Arthropoda 1: Trilobita 1 (pp. 331-383). Geological Society of America and University of Kansas.

Ulrich, E. O., \& Cooper, G. A. (1936). New genera and species of Ozarkian and Canadian brachiopods. Journal of Paleontology, 10, 616-631.

Wahlenberg, G. (1818). Petrificata Telluris Svecanae.Nova Acta Regiae Societatis Scientarium Upsaliensis, $8,1-116$.

Walcott, C. D. (1920). Cambrian geology and paleontology (Vol. IV, No. 6: Middle Cambrian Spongiae). Smithsonian Miscellaneous Collections, 67, 261-364.

Webby, B. D. (1973). Remopleurides and other Upper Ordovician trilobites from New South Wales. Palaeontology, 16, 445-475. 
Whittington, H. B., \& Evitt, W. R. (1953). Silicified Middle Ordovician trilobites. Geological Society of America Memoir, 59, 1-137. https://doi.org/10.1130/MEM59-p1

Williams, A., Carlson, S. J., Brunton, C. H. C., Holmer, L. E., \& Popov, L. E. (1996). A supra-ordinal classification of the Brachiopoda. Philosophical Transactions of the Royal Society of London (series B), 351, 1171-1193. https://doi.org/10.1098/rstb.1996.0101

Williams, A., \& Harper, D. A. T. (2000). Protorthida and Orthida. In R. L. Kaesler (Ed.), Treatise on Invertebrate Paleontology, Part H, Brachiopoda, Revised (Vol. 3) (pp. 709-782). Geological Society of America and University of Kansas. https://doi.org/10.17161/dt.v0i0.5212

Withnall, I. W., \& Lang, S. C. (Eds.). (1993). Geology of the Broken River Province, north Queensland. Queensland Geology, 4, 1-289.

Yabe, H., \& Hayasaka, I. (1920). Palaeontology of southern China. Geographical Research in China, 1911-1916, Report 3. Tokyo Geographical Society.

Zhen, Y. Y., Percival, I. G., \& Molloy, P. D. (2015). Late Ordovician conodonts and brachiopods from near Greenvale in the Broken River Province, north Queensland. Proceedings of the Linnean Society of New South Wales, 137, 85-133.

Zhou, Z. Y., Dean, W. T., Yuan, W. W., \& Zhou, T. R. (1998). Ordovician trilobites from the Dawangou Formation, Kalpin, Xinjiang, north-west China. Palaeontology, 41, 693-735.

Zhou, Z. Y., Yin, G. Z., \& Zhou, T. R. (2014). Ordovician (Darriwilian - early Katian) trilobite faunas of northwestern Tarim, Xinjiang, China. Australasian Palaeontological Memoirs, 46, 1-142.

\section{Author Profiles}

Peter Jell is an Adjunct Professor of The University of Queensland and a Research Associate of the Queensland Museum. He is a former Curator and Deputy Director, Scientific and Collections of the Queensland Museum, with 50 years' experience studying Queensland palaeontology. He was the sole editor and one of 60 contributors to the landmark 2012 book Geology of Queensland, published by the Geological Survey of Queensland.

Ian Percival is an Honorary Research Associate of the Geological Survey of New South Wales, where he formerly was employed as Palaeontologist from 1995-2018. He specialises in the study of early Palaeozoic brachiopods and conodonts. From 2008-2020, he was the Australian representative on the Subcommission for Ordovician Stratigraphy, serving as its Secretary from 2012.

Alex Cook is a Research Associate and former Curator of Invertebrate Palaeontology at the Queensland Museum. He has wide experience of Queensland geology, having published widely on many aspects; he was a major contributor to Geology of Queensland, and principal author of the Queensland Museum's In Search of Ancient Queensland. 